\title{
Moderasi Norma Sosial dan Keterlibatan Personal terhadap Perilaku Peduli Lingkungan
}

\section{Moderation of Social Norms and Personal Involvement of Pro-Environmental Behavior}

\author{
Yogi Pambudi, Ni Putu Pristi Wisuantari \\ Fakultas Psikologi Universitas Indonesia, Depok, Indonesia
}

\begin{abstract}
Pro-environmental behavior is a solution to overcome environmental problems. Plastic straw waste, which was produced majorly from restaurant's consumption, has been identified as one of the causes of the environmental damage. This research was conducted to examine the moderation effect of social norms to plastic straw usage among restaurant visitors. The uantitative method was used by using self-report questionnaires to measure descriptive norm, injunctive norm, and personal involvement. Data were collected from 106 respondents whose ages ranged from 18 to 54 years with the proportion of $44 \%$ male and $66 \%$ female. This study has four hypotheses, namely the injunctive norm moderates the relationship between descriptive norm and pro-environment behavior, personal involvement moderates the relationship between descriptive norm and proenvironmental behavior, descriptive norm moderates the relationship between injunctive norm and pro-environmental behavior, and personal involvement moderates the relationship between injunctive norm and pro-environmental behavior. Statistical analysis using IBM SPSS with the add-on PROCESS Hayes 3.4 was used to test the moderation effect. The study found that there are no significant results from the four hypotheses. Although all hypotheses were not proven, the descriptive norm was proved to have a moderation effect to relationship between the injunctive norm and pro-environmental behavior when the score of descriptive norms is moderate or high. Hence, injunctive norm has potential to increase pro-environment behavior when it is moderated by moderate or high levels of descriptive norm.
\end{abstract}

Keywords: Descriptive norm, injunctive norm, personal involvement, proenvironmental behavior

\begin{abstract}
Abstrak: Perilaku peduli lingkungan adalah solusi untuk mengatasi masalah lingkungan. Salah satu penyebab masalah lingkungan dengan begitu banyaknya sampah sedotan plastik. Penelitian ini menguji interaksi moderasi dari norma sosial dan keterlibatan personal terhadap perilaku peduli lingkungan pada pengunjung restoran terkait penggunaan sedotan plastik. Penelitian ini menggunakan metode kuantitatif terhadap 106 responden dengan rentang usia dari 18 - 54 tahun dan proporsi gender pria $44 \%$ dan perempuan $66 \%$. Instrumen yang digunakan adalah alat ukur norma deskriptif, norma injungtif, dan keterlibatan personal. Penelitian ini menguji empat hipotesis, yakni; norma injungtif memoderasi norma deskriptif terhadap perilaku peduli lingkungan, keterlibatan personal memoderasi norma deskriptif terhadap perilaku peduli lingkungan, norma
\end{abstract}

Korespondensi tentang artikel ini dapat dapat ditujukan pada Yogi Pambudi melalui e-mail: yogipambudi27@gmail.com 
deskriptif memoderasi norma injungtif terhadap perilaku peduli lingkungan, dan keterlibatan personal memoderasi norma injungtif terhadap terhadap perilaku peduli lingkungan. Analisis statistik menggunakan IBM SPSS dengan add-on PROCESS Hayes 3.4 untuk melihat efek moderasi tersebut. Hasilnya, keempat hipotesis tidak terbukti. Meskipun keempat hipotesis ditolak tetapi norma deskriptif, ketika berada nilai moderat dan tinggi, memiliki pengaruh interaksi dalam memoderasi peran norma injungtif terhadap perilaku peduli lingkungan, Sehingga norma injungtif yang dimoderasi oleh norma deskriptif berpotensi untuk meningkatkan perilaku peduli lingkungan.

Kata kunci: Keterlibatan personal, norma deskriptif, norma injungtif, perilaku peduli lingkungan

Permasalahan lingkungan terus menjadi sorotan dalam beberapa dekade terakhir. Perubahan iklim dan berbagai kerusakan lingkungan adalah masalah utama lingkungan yang berdampak pada keberlangsungan hidup manusia (Steffen et al., 2015). Salah satu penyebab kerusakan lingkungan adalah sampah plastik. Indonesia masih menghadapi kesulitan dalam mengelola sampah plastik. Sebanyak 3.2 juta ton sampah plastik di Indonesia tidak dikelola dengan baik, dan 1.29 juta ton sampah plastik berakhir di laut (Jambeck et al., 2015). Sampah laut yang dihasilkan oleh Indonesia merupakan terbanyak kedua di dunia (Tibbetts, 2015). Berdasarkan uraian tersebut permasalahan mengenai sampah, khususnya plastik menjadi tidak bisa diabaikan.

Berbagai penelitian telah mengkaji faktor psikologis dalam perilaku peduli lingkungan. Keputusan seseorang cenderung terpengaruh oleh berbagai faktor untuk mengambil tindakan peduli lingkungan. Hal yang mempengaruhi seseorang untuk berperilaku peduli lingkungan disebabkan oleh keadaan sekitar dan identitas sosial (Dono, Webb, dan Richardson, 2010). Beberapa teori besar dalam psikologi yang melakukan upaya untuk peningkatan peduli lingkungan seperti; theory of planned behavior (Ajzen, 2011), norm activation model (J. De Groot \& Steg, 2009) dan focus theory of normative conduct (Cialdini, Reno, \& Kallgren, 1990) telah dilakukan.
Keadaan sekitar mampu memengaruhi seseorang dalam bertindak peduli lingkungan. Penelitian Cialdini, Kallgren, dan Reno (1991) menunjukan bahwa lingkungan yang tidak ada sampah cenderung membuat seseorang untuk tidak membuang sampah sembarangan. Sebaliknya jika di suatu tempat banyak sampah berserakan, maka seseorang pun lebih mudah membuang sampah sembarangan. Pengaruh sosial yang muncul memicu untuk orang lain bertindak sesuai dengan keadaan.

Pengaruh sosial merupakan proses yang selalu terjadi dalam kehidupan sehari-hari, dan hal ini mampu memengaruhi perilaku kita dalam kehidupan sosial (Cialdini \& Trost, 1998). Memahami pengaruh sosial dapat melalui dua hal, seperti yang dijelaskan oleh Abrams \& Hogg (1990), yaitu bagaimana seseorang melakukan penyesuaian atas identitas sosial (social identity) dan kategori diri (selfcategorization) terhadap keadaan sekitar. Sedangkan, menurut Cialdini \& Trost (1998), terdapat tiga komponen yang membuat pengaruh sosial dapat membentuk suatu perilaku, yakni; norma sosial, konformitas dan kepatuhan. Pertimbangan pengaruh sosial juga terbentuk dari individu dan lingkungan yang tercipta dari banyaknya interaksi antar kedua hal tersebut.

Salah satunya yang semakin mendapatkan perhatian akhir-akhir ini adalah perkembangan norma sosial sebagai 
faktor yang mampu mengarahkan perilaku seseorang. Norma sosial tidak hanya digunakan di lingkup riset, tetapi telah diterapkan juga pada praktik lapangan dengan spektrum yang cukup luas (Nyborg et al., 2016). Norma sosial telah diuji coba pada berbagai kasus, dengan kombinasi berbagai disiplin ilmu, seperti ekonomi dan kebijakan publik.

Namun, interaksi norma sosial pada keadaan sekitar juga dapat memengaruhi perilaku seseorang. Seperti adanya efek moderasi terhadap norma sosial yang mendorong perilaku peduli lingkungan (Göckeritz et al., 2010). Karena itu, penelitian ini bertujuan untuk menguji peran moderasi dari norma sosial dan keterlibatan personal pada perilaku peduli lingkungan.

Kehadiran orang lain mampu memberi pengaruh cukup besar dalam mengarahkan suatu perilaku tertentu, hal tersebut terjadi karena adanya norma sosial di sekitar kita (Cialdini \& Goldstein, 2004). Norma sosial sudah diterapkan ke dalam berbagai langkah strategi intervensi untuk mengarahkan ataupun mengubah perilaku seseorang (Miller \& Prentice, 2016), penggunaan pesan normatif merupakan upaya memberikan penekanan terhadap norma sosial agar individu dapat terarahkan perilakunya. Sehingga memberikan persepsi yang dominan terhadap norma sosial sering diupayakan dalam berbagai kampanye agar mampu merubah perilaku.

Keyakinan individu pada norma sosial merupakan proses mendasar yang menjadi landasan dalam bertindak, dan hal ini dapat diterapkan dalam kehidupan sehari-hari (Wesley Schultz, Tabanico, \& Rendón, 2011). Norma sosial juga dapat memunculkan konformitas yang dapat membuat orang lain mengikuti tindakan yang diinginkan sehingga pada akhirnya dapat melahirkan efek domino (Cialdini \& Trost, 1998). Kehadiran norma sosial di tengah kehidupan kita dapat dirasakan atau tidak sama sekali, meskipun begitu tetap memberikan pengaruh pada perilaku setiap individu.

Norma sosial membuktikan dapat mengarahkan perilaku seseorang secara tidak sadar atau tanpa sebuah paksaan (Nolan, Schultz, Cialdini, Goldstein, \& Griskevicius, 2008). Seseorang yang terpengaruh dengan norma sosial tidak menyadari dengan kehadiran norma sosial itu sendiri. Sedangkan menurut Cialdini, Reno, dan Kallgren (1990) dalam focus theory of normative conduct, terdapat dua norma yang mengarahkan seseorang untuk berperilaku, yakni; norma deskriptif dan injungtif.

Norma deskriptif merupakan panduan berperilaku berdasarkan informasi yang didapatkan dari perilaku yang ada di sekitar kita, semakin banyak yang melakukan suatu hal pada suatu konteks maka akan menjadi norma deskriptif (Cialdini et al., 1990). Selanjutnya, norma injungtif adalah perilaku yang tindak tanduknya memperhitungkan konsekuensi yang akan terjadi, sehingga seseorang akan cenderung melakukan sesuatu untuk mendapatkan penghargaan atau menghindari sanksi sosial (Cialdini et al., 1991). Sederhananya, norma deskriptif adalah perilaku mayoritas kelompok yang terjadi, dan norma injungtif merupakan perilaku yang seharusnya dilakukan oleh seseorang untuk membentuk suatu keadaan ideal (Cialdini, 2007).

Dalam kehidupan sehari-hari, seseorang seringkali menggunakan norma sosial sebagai panduan dalam berperilaku. Misalnya ketika, seseorang datang ke tempat baru dan belum mengenal tata cara berperilaku, sehingga akan mengandalkan norma yang berlaku untuk bertindak tanduk. Norma sosial akan menjadi petunjuk yang informatif untuk seseorang beradaptasi dalam berbagai keadaan.

Perilaku seseorang terjadi dan terpengaruh pada keterlibatan individu yang bersumber dari konsep dirinya (Johnson \& Eagly, 1989). Faktor-faktor yang membentuk keterlibatan pada suatu hal terdiri 
dari tiga, yakni; nilai yang dianut, perilaku yang diinginkan, dan keinginan untuk memberikan impresi pada orang lain (Johnson \& Eagly, 1989). Semakin tinggi tiga hal tersebut pada perilaku yang diinginkan, maka semakin tinggi pula berperilaku yang diharapkan terjadi.

Ketertarikan individu pada sesuatu mampu meningkatkan keterlibatan personal pada isu tertentu yang dinilai menarik. Isu-isu tertentu yang menarik oleh seseorang dapat menggerakan pada perilaku spesifik, jika seseorang terlibat pada isu kebersihan, maka seseorang tersebut akan lebih mudah berperilaku menjaga kebersihan. Pesan persuasif lebih efektif jika seseorang memiliki isu keterlibatan personal yang sama dengan pesan tersebut (Petty, Cacioppo, \& Goldman, 1981).

Penggunaan keterlibatan personal telah diuji, pada pengukuran tingkat pembelian daring yang dilakukan, bahwa keterlibatan personal merupakan faktor penentu terjadinya belanja daring (Zhao, Chen, \& Zhang, 2019). Produk tertentu yang memiliki kesamaan dengan konsep diri pada keterlibatan personal seseorang menjadi indikasi penting terjadinya pembelian (Taylor, Bing, Reynolds, Davison, \& Ruetzler, 2018). Karena itu, keterlibatan personal memiliki pengaruh terhadap perilaku seseorang, selama sesuai dengan konsep diri yang dimiliki.

Keterlibatan personal juga mampu memoderasi dalam meningkatkan perilaku yang diharapkan (Bai et al., 2018, 2019). Keterlibatan personal dapat menjadi moderasi pada hubungan norma sosial dan perilaku peduli lingkungan (Göckeritz et al., 2010). Pada penelitian ini, keterlibatan personal diuji kembali menjadi moderator pada hubungan norma sosial dan perilaku peduli lingkungan.

Penggunaan keterlibatan personal telah digunakan untuk melakukan intervensi perubahan perilaku. Salah satu contohnya adalah penggunaan pesan framing yang melibatkan keterlibatan personal menunjukan perubahan perilaku.
Penerapan norma sosial di kajian ilmiah telah dilakukan dalam berbagai konteks. Salah satunya untuk mengatasi permasalahan lingkungan, dan meningkatkan perilaku peduli lingkungan. Misalnya, pemberian pesan normatif untuk mengurangi penggunaan kantong plastik (de Groot, Abrahamse, \& Jones, 2013), mempersuasi untuk mengurangi penggunaan botol plastik (van der Linden, 2015), mengurangi penggunaan handuk sekali pakai di hotel (Goldstein, Cialdini, \& Griskevicius, 2008), dan penelitian yang cukup klasik pada perilaku buang sampah (Cialdini et al., 1990).

Norma sosial telah menjadi penelitian yang mendorong perubahan perilaku, dan permasalahan pada akhir-akhir ini terkait kerusakan lingkungan. Perlu adanya penerapan kajian ilmiah yang lebih banyak untuk mengatasi permasalahan lingkungan. Penelitian kali ini akan mendalami peran moderasi dari norma deskriptif, injungtif dan keterlibatan personal sebagai faktor pendorong perilaku peduli lingkungan. Salah satu permasalahan lingkungan yang diangkat adalah penggunaan sedotan plastik di restoran, bagaimana norma sosial mampu mendorong seseorang untuk berperilaku mengurangi sedotan plastik tersebut.

Sampah plastik merupakan permasalahan cukup serius. Produksi sampah plastik Indonesia termasuk terbanyak kedua di lautan, luas sampah yang dihasilkan seperti pulau yang mengapung di laut (Tibbetts, 2015). Begitu pula sedotan plastik menjadi komoditas favorit yang terbuang di laut (Ocean Conservancy, 2017). Maka diperlukan penggalian lebih dalam untuk mengurangi penggunaan sedotan plastik, terutama dengan pendekatan norma sosial.

Penggunaan norma sosial sebagai moderasi sudah terbukti berhasil dalam mengarahkan perilaku, sehingga norma sosial teruji menjadi strategi intervensi perubahan perilaku (Park, Son, Lee, \& Go, 2020). Menurut Rimal dan Real (2005), 
ada hubungan moderasi antara norma deskriptif dan perilaku. Argumennya menyatakan bahwa perilaku yang dihasilkan muncul karena adanya identitas kelompok, dan norma injungtif yang memoderasi untuk mempengaruhi norma deskriptif dalam mendorong perilaku seseorang. Semakin tinggi bentuk penerimaan atau penghargaan sosial yang dihasilkan dari norma injungtif meningkatkan keberhasilan norma deskriptif dalam membentuk perilaku seseorang (Rimal \& Real, 2005). Pertanyaan ini juga dibuktikan oleh penelitian lainnya, yang menunjukkan bahwa referensi kelompok menjadi faktor penting seseorang untuk berperilaku (McAuliffe, Jetten, Hornsey, \& Hogg, 2003; Terry \& Hogg, 1996).

Mekanisme moderasi norma injungtif dan keterlibatan personal pada norma deskriptif untuk meningkatkan perilaku peduli lingkungan juga ditunjukan dalam penelitian Göckeritz et al. (2010). Oleh karena itu norma injungtif dan keterlibatan personal dapat memoderasi norma deskriptif secara positif terhadap sikap peduli lingkungan. Berdasarkan temuan yang sudah dilakukan oleh Göckeritz etc. Keterlibatan personal sebagai moderasi juga mampu memunculkan perilaku yang diharapkan, keberadaan keterlibatan personal menghasilkan pengaruh signifikan pada pemberian pesan persuasif (Bai et al., 2018, 2019). Seseorang cenderung lebih tertarik pada pesan yang sesuai dengan keterlibatan personalnya sehingga pesan persuasif yang diberikan jadi lebih efektif. Keterlibatan personal mampu menjadi moderasi dalam mengarahkan perilaku yang diharapkan. Pada penelitian ini pun menguji hipotesis 1 dan 2 ialah sebagai berikut:

H1: Norma injungtif mampu memoderasi norma deskriptif terhadap perilaku peduli lingkungan.

H2: Keterlibatan personal mampu memoderasi norma deskriptif terhadap perilaku peduli lingkungan.
Namun, tidak menutup untuk sebaliknya, yakni norma deskriptif menjadi moderator untuk norma injungtif dalam mendorong perilaku peduli lingkungan. Penelitian belakangan ini menunjukan bahwa norma injungtif juga memiliki peran cukup penting dalam mengarahkan perilaku seseorang, sehingga peran norma injungtif perlu diperhitungkan lebih jauh lagi (Estrada et al., 2014; Greenaway et al., 2012; Vesely \& Klöckner, 2018). Keterlibatan personal juga telah menjadi moderasi pada norma sosial (Göckeritz et al., 2010), dan pada pesan persuasif dalam mengarahkan perilaku menjelaskan bahwa keterlibatan personal juga menjadi moderasi yang cukup ber-pengaruh (Bai et al., 2018; 2019). Demikian, hipotesis 3 dan 4 adalah sebagai berikut:

H3: Norma deskriptif mampu memoderasi norma injungtif terhadap perilaku peduli lingkungan

H4: Keterlibatan personal mampu memoderasi norma injungtif terhadap perilaku peduli lingkungan.

Dengan begitu, manfaat norma sosial sangat erat dalam kehidupan sehari-hari. Harapannya ialah mengetahui bagaimana mekanisme norma sosial dalam moderasi dapat digunakan lebih luas untuk kebaikan bersama, terutama penyelesaian masalah lingkungan.

\section{Metode}

\section{Partisipan}

Partisipan diseleksi menggunakan teknik non-probability sampling, yaitu convenience sampling. Pertimbangan ini dilakukan karena peneliti sebelumnya menjalin hubungan dengan pemilik restoran untuk melakukan riset terkait penggunaan sedotan pada pengunjung. Oleh karena itu, peneliti melakukan pengambilan data pada pengunjung yang datang di restoran, dengan kualifikasi usia 18 tahun atau lebih, dan bersedia mengisi kue- 
sioner. Pengumpulan data dilakukan selama delapan hari, pada waktu antara pukul 16.00 hingga 21.00. Pengambilan data dilakukan pada dua restoran dengan karakteristik restoran yang memiliki kesamaan, hal ini disebabkan kedua restoran tersebut merupakan satu merek yang sama. Lokasi kedua restoran tersebut berada di Jakarta.

Peneliti memberikan kuesioner mengenai perilaku yang berkaitan dengan penggunaan sedotan plastik pada pengunjung. Hal ini bertujuan untuk mengetahui kebiasaan pengunjung dalam penggunaan sedotan plastik, dan anggapan terhadap dampak dari sedotan plastik itu sendiri. Pemilihan restoran disebabkan terdapat perilaku penggunaan sedotan plastik. Restoran memiliki ketergantungan tinggi terhadap sedotan plastik tersebut.

Pengumpulan data kuesioner dilakukan selama delapan hari di dua restoran tersebut. Total kuesioner terkumpul adalah 109 eksemplar, tetapi tiga dari kuesioner tidak terisi dengan penuh, sehingga hanya 106 kuesioner yang dapat diolah. Lima puluh enam kuesioner didapatkan dari Restoran 1 dan lima puluh tiga kuesioner didapatkan dari Restoran 2.

Dari 106 responden, didapatkan data demografi ialah $76 \%$ berusia antara 20-30 tahun, $12 \%$ berusia 15-19 tahun, dan usia 31 tahun ke atas sekitar $11 \%$. Sebagian besar berprofesi sebagai karyawan swasta (61\%), mahasiswa dan pelajar $(25 \%)$. Perbandingan gender, pria $44 \%$ dan perempuan $56 \%$. Dengan pendidikan didominasi dari jenjang S1 (46\%) dan setingkat SMA (44\%).

\section{Pengumpulan Data}

Penelitian ini mengukur norma sosial yang dimiliki oleh pengunjung dengan menggunakan alat ukur yang telah diadaptasi (Göckeritz et al., 2010). Dengan mengukur empat variabel, yakni; norma deskriptif, norma injungtif, keterlibatan personal dan perilaku peduli lingkungan. Pertanyaan adaptasi disesuaikan dengan kasus penggunaan sedotan plastik.

Alat ukur norma deskriptif terdiri dari 4 pertanyaan, yakni; Apakah menurut Anda pengunjung yang lain tidak menggunakan sedotan plastik ketika meminum?; Apakah menurut Anda sebagian besar warga Jakarta tidak menggunakan sedotan plastik ketika meminum?; Apakah menurut Anda sebagian besar warga Indonesia tidak menggunakan sedotan plastik ketika meminum?; Apakah menurut Anda bahwa teman-teman Anda tidak menggunakan sedotan plastik ketika meminum? Cronbach's $\alpha$ untuk keempat pertanyaan tersebut adalah .64. Skor tersebut menunjukan bahwa alat ukur norma deskriptif cukup andal dan dapat diterima (Hair, Black, Babin \& Anderson, 2018). Validtas alat ukur norma deskriptif terdapat pada rentang skor $0.30-0.57$, menyatakan bahwa aitem layak digunakan.

Alat ukur norma injungtif terdiri dari tiga (3) pertanyaan, yakni; Apakah menurut Anda pengunjung lainnya menyetujui bahwa tidak menggunakan sedotan plastik merupakan salah satu cara mengurangi sampah plastik?; Apakah menurut Anda sebagian besar warga Jakarta sepakat bahwa tidak menggunakan sedotan plastik merupakan salah satu cara mengurangi sampah plastik?; Apakah menurut Anda sebagian besar warga Indonesia sepakat bahwa tidak menggunakan sedotan plastik merupakan salah satu cara mengurangi sampah plastik?; Cronbach's $\alpha$ untuk ketiga pertanyaan tersebut adalah .83. Angka tersebut memiliki makna bahwa alat ukur dari norma injungtif sangat andal (Hair et al., 2018). Validitas alat ukur norma injungtif berada pada skor 0.67-0.71, menjelaskan bahwa aitem tersebut valid.

Alat ukur Keterlibatan Personal diukur melalui empat pertanyaan, yakni; Seberapa sering Anda berpikir untuk mengurangi penggunaan plastik?; Sebe- 
rapa penting menjaga lingkungan untuk Anda?; Seberapa peduli Anda dengan gerakan peduli lingkungan?; Seberapa paham Anda mengenai perilaku peduli lingkungan?; Cronbach's $\alpha$ untuk ketiga pertanyaan tersebut adalah .81 yang bermakna bahwasannya alat ukur keterlibatan personal sangat andal (Hair et al., 2018), untuk validitas alat ukur keterlibatan personal ialah $0.50-0.77$ yang dapat dimaknai bahwa aitem valid.

Pengukuran perilaku peduli lingkungan melalui satu pertanyaan, yakni; Seberapa sering Anda berusaha melakukan gerakan peduli lingkungan? (hemat air/listrik, pengelolaan sampah secara tepat, mengurangi penggunaan plastik, dan lainnya).

Keempat alat ukur tersebut menggunakan empat skala, yaitu; Hampir Tidak Pernah (1), Jarang (2), Sering (3), dan Hampir Selalu (4). Selanjutnya dilengkapi dengan pertanyaan tambahan tentang data diri dan kebiasaan berkunjung ke restoran dari responden.

\section{Teknik Analisis Data}

Data penelitian ini dianalisis menggu-nakan bantuan aplikasi IBM SPSS versi 2.6. Keempat hipotesis penelitian ini diuji menggunakan PROCESS Hayes versi 3.4 (Hayes \& Little, 2018). Selama proses analisis, diterapkan pembersihan data agar proses perhitungan dapat berjalan dengan baik.

\section{Hasil}

\section{Gambaran Deskriptif}

Data deskriptif diperoleh melalui pertanyaan mengenai gambaran umum partisipan di restoran dengan tujuan untuk mengetahui perilaku pengunjung restoran terkait perilaku penggunaan sedotan plastik. Tabel 1 menampilkan dari data tersebut.
Tabel 1. Gambaran Deskriptif

\begin{tabular}{lc}
\hline Pernyataan & \% \\
\hline $\begin{array}{l}\text { Pengunjung restoran hampir selalu } \\
\text { menggunakan sedotan plastik }\end{array}$ & 93 \\
$\begin{array}{l}\text { Pengunjung menggunakan sedotan } \\
\text { karena disediakan }\end{array}$ & 68 \\
$\begin{array}{l}\text { Pengunjung menggunakan sedotan } \\
\text { karena terbiasa }\end{array}$ & 23 \\
$\begin{array}{l}\text { Pengunjung menggunakan sedotan } \\
\text { karena mengalami gangguan (contoh: }\end{array}$ & 3 \\
gigi sensitif) & \\
$\begin{array}{l}\text { Responden merasa sebagian besar } \\
\text { pengunjung restoran menggunakan }\end{array}$ & 77 \\
$\begin{array}{l}\text { sedotan selama meminum } \\
\text { Responden setuju bahwa tidak } \\
\text { menggunakan sedotan plastik } \\
\text { merupakan perilaku peduli }\end{array}$ & 54 \\
lingkungan
\end{tabular}

Berdasarkan tabel di atas, dapat dipahami kebiasaan penggunaan sedotan plastik oleh responden, dan alasan menggunakannya. Kemudian dapat dilihat bahwa norma deskriptif pada pengun-jung restoran ialah menggunakan se-dotan selama minum (77\%), dan norma injungtif menunjukan sebaliknya yakni mendukung gerakan peduli lingkungan yang menyatakan bahwa tidak menggu-nakan sedotan plastik merupakan peri-laku peduli lingkungan (54\%).

\section{Hasil Uji Hipotesis}

Analisis pertama menguji fungsi moderasi norma injungtif terhadap norma deskriptif dengan perilaku peduli lingkungan. Perhitungan analisis menggunakan PROCESS Model 1 (Hayes \& Little, 2018) dengan perhitungan model moderasi $\mathrm{F}(3,102)=3.67, \mathrm{p}<.014, \mathrm{R} 2=.12$ menunjukkan bahwa model moderasi diterima. Kemudian, norma deskriptif tidak dapat menjadi prediksi peningkatan perilaku peduli lingkungan, dengan hasil perhitungan $\mathrm{b}=-.191, \mathrm{t}(102)=-1,72$, $\mathrm{p}=.089$, hal ini menyatakan tidak signifi- 


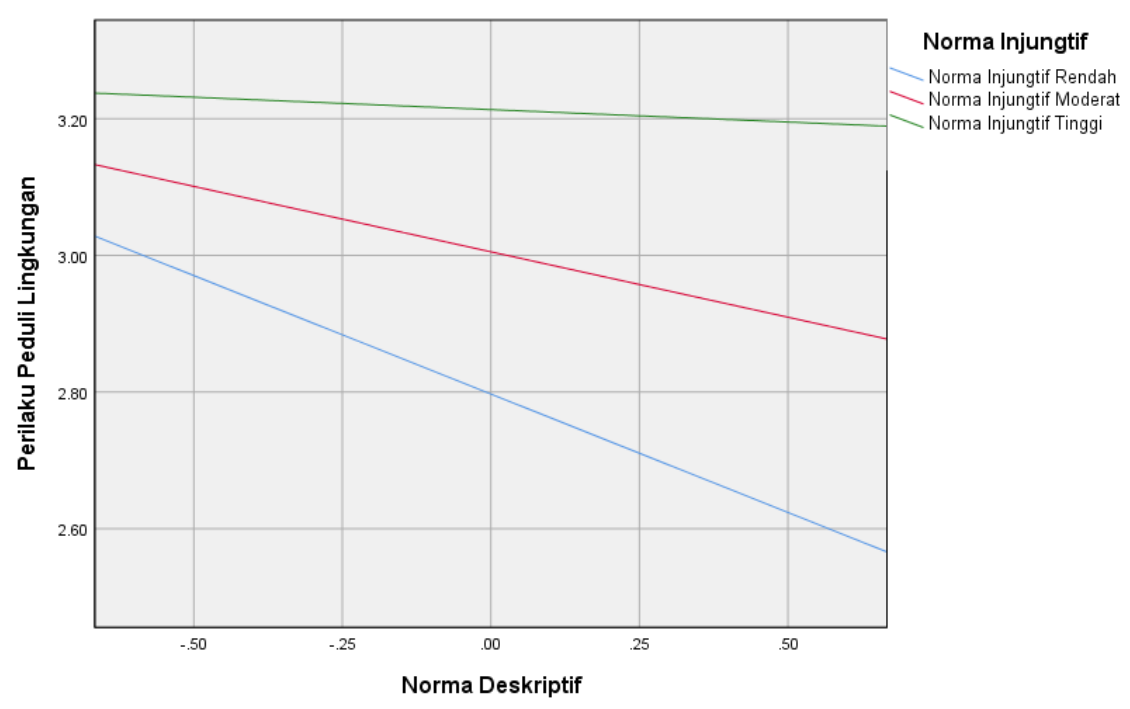

Gambar 1. Interaksi moderasi norma injungtif terhadap norma deskriptif dan perilaku peduli lingkungan

kan. Selanjutnya, norma injungtif memiliki pengaruh memprediksi perilaku peduli lingkungan dengan hasil $b=.29$, $t(102)=2.52, p=.01$, sehingga setiap kenaikan satu poin norma injungtif juga meningkatkan perilaku peduli lingkungan sebesar .29. Sedangkan untuk interaksi moderasi norma injungtif terhadap hubungan norma deskriptif dan perilaku peduli lingkungan tidak signifikan $(b=.21$, $\mathrm{t}(102)=1.21, \mathrm{p}=.29)$.

Gambar 1 merupakan interpretasi dari analisis Johnson-Neyman, yakni pengaruh interaksi moderasi ditunjukan hanya pada norma injungtif yang bernilai rendah. Sehingga analisis dari H1 ditolak, meskipun begitu masih memiliki efek moderasi pada norma injungtif bernilai rendah, meskipun hanya sebagian kecil. Norma injungtif pada kasus penggunaan sedotan plastik dapat mempengaruhi norma deskriptif terhadap perilaku peduli lingkungan, jika norma injungtif berada pada kategori rendah.

Kedua, melakukan analisis pada $\mathrm{H} 2$, moderasi diterima dengan nilai $\mathrm{F}(3$, 36) $=10.26, p<.001, R 2=.31$. Norma deskriptif tidak signifikan terhadap perilaku peduli lingkungan $(b=-1.56, t(36)=-1.32$, $\mathrm{p}=.19$ ). Keterlibatan personal memiliki pengaruh signifikan senilai $\mathrm{b}=.67$, $\mathrm{t}(36)=4.04, \mathrm{p}=.00$, sehingga setiap kenaikan satu unit dari keterlibatan personal maka terjadi kenaikan nilai .67 pada perilaku peduli lingkungan. Interaksi moderasi keterlibatan personal terhadap hubungan norma deskriptif yang menyatakan bahwa model dengan perilaku peduli pada lingkungan tidak signifikan $(b=.22$, $\mathrm{t}(36)=.74, \mathrm{p}=.45)$. Perhitungan JohnsonNeyman menunjukkan bahwa tidak ada interaksi moderasi keterlibatan personal, baik pada nilai keterlibatan personal rendah, moderat atau tinggi. Grafik dapat dilihat pada Gambar 2.

Berdasarkan perhitungan tersebut, H2 ditolak. Hasil tersebut menunjukkan keterlibatan personal sama sekali tidak membawa pengaruh terhadap perilaku peduli lingkungan, baik pada kategori keterlibatan personal rendah, moderat ataupun tinggi. Sehingga keterlibatan personal tidak dapat mempengaruhi dalam memoderasi norma deskriptif pada perilaku peduli lingkungan.

Ketiga, analisis pada $\mathrm{H} 3$, model perhitungan diterima dengan nilai $\mathrm{F}(3,102)$ $=3.671, \mathrm{p}<.014, \mathrm{R} 2=.35$. Norma injungtif signifikan memiliki pengaruh dengan hasil perhitungan $b=.286$ terhadap perilaku peduli lingkungan $t(102)=2.519$, $\mathrm{p}=.013$, yang berarti setiap kenaikan satu 


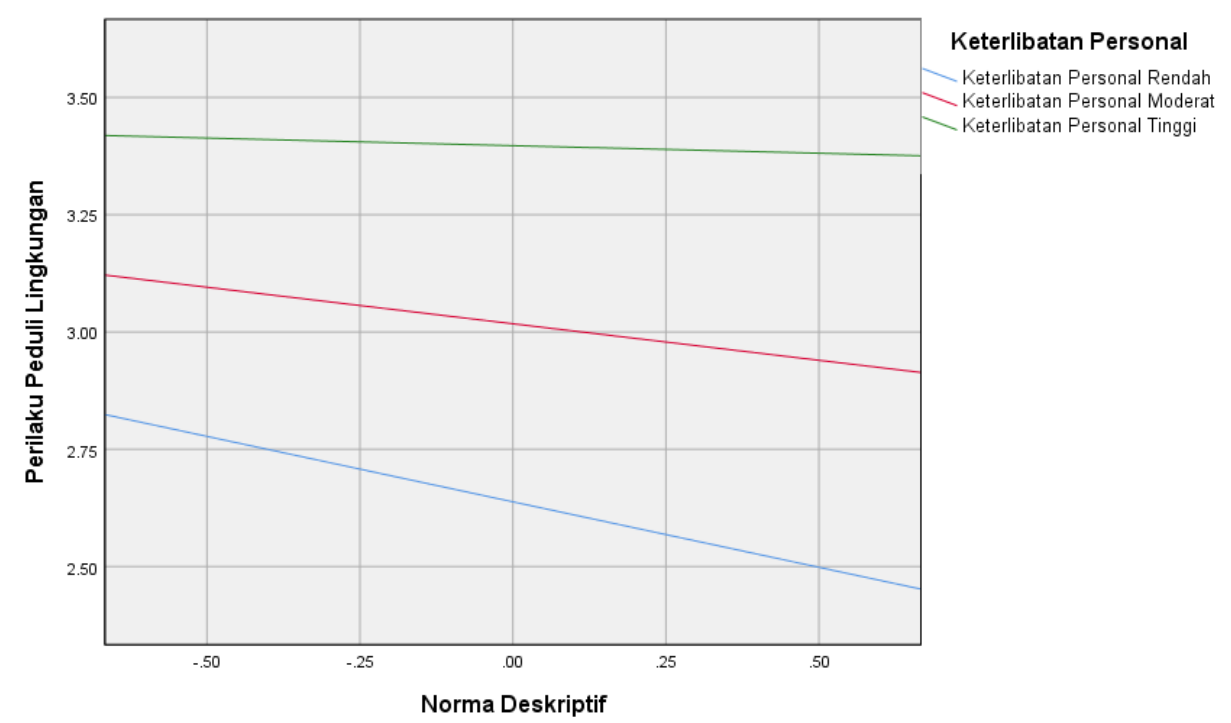

Gambar 2. Interaksi moderasi keterlibatan personal terhadap norma deskriptif dan perilaku peduli lingkungan

unit norma injungtif maka terjadi kenaikan sebesar .286 terhadap perilaku peduli lingkungan. Norma deskriptif tidak memiliki pengaruh terhadap perilaku peduli lingkungan $(b=-.191, t(102)=-1.721, p=$ .088). Interaksi moderasi norma deskriptif terhadap peran norma injungtif terhadap perilaku peduli lingkungan tidak signifikan $(b=.213, t(102)=.213, \mathrm{p}=.228)$. Sedangkan jika melihat perhitungan JohnNeyman, interaksi moderasi norma deskriptif pada hubungan norma injungtif dan perilaku peduli lingkungan cukup baik, bahwa adanya interaksi pada nilai norma des-kriptif moderat dan tinggi yang signi-fikan, meskipun nilai norma deskriptif rendah tidak memiliki pengaruh signi-fikan, Grafik John-Neyman dapat dilihat pada Gambar 3. Meskipun H3 ditolak, tetapi Sebagian nilai signifikan (nilai norma deskriptif moderat dan tinggi), oleh karena itu memiliki potensi memprediksi perilaku peduli lingkungan. Maka dari itu, potensi terbesar dalam me-

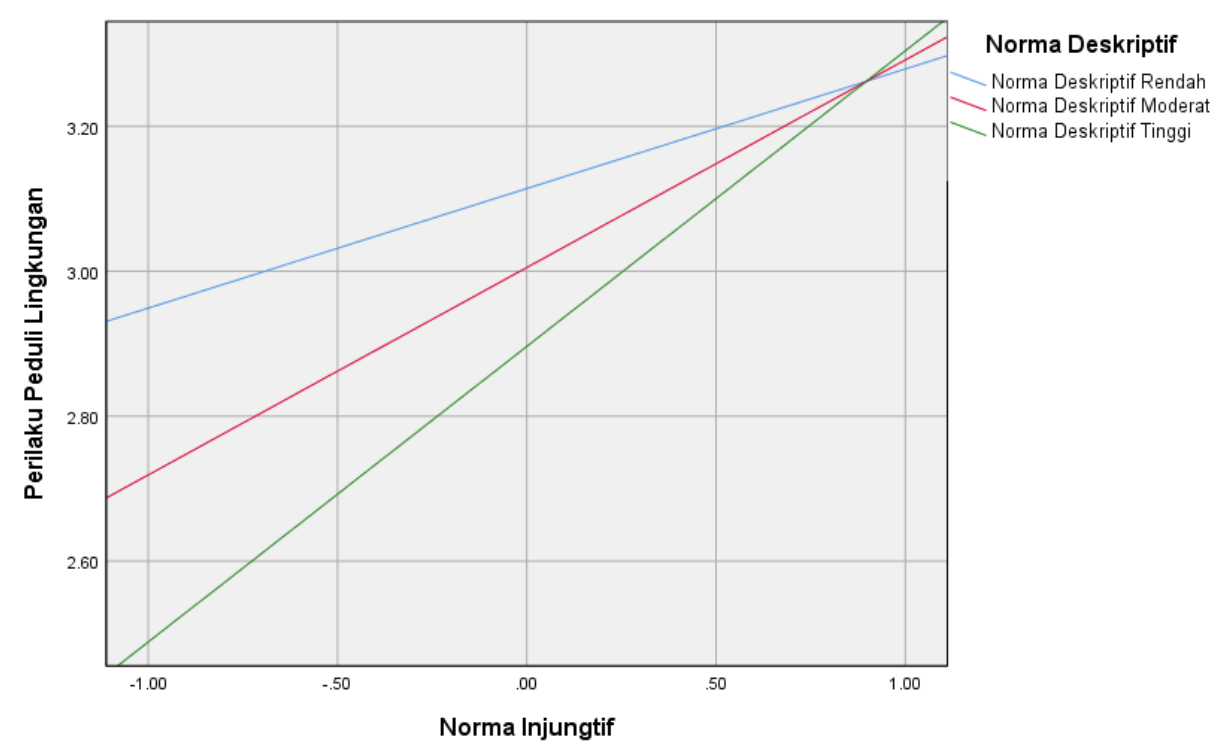

Gambar 3. Interaksi moderasi norma deskriptif terhadap norma injungtif dan perilaku peduli lingkungan 


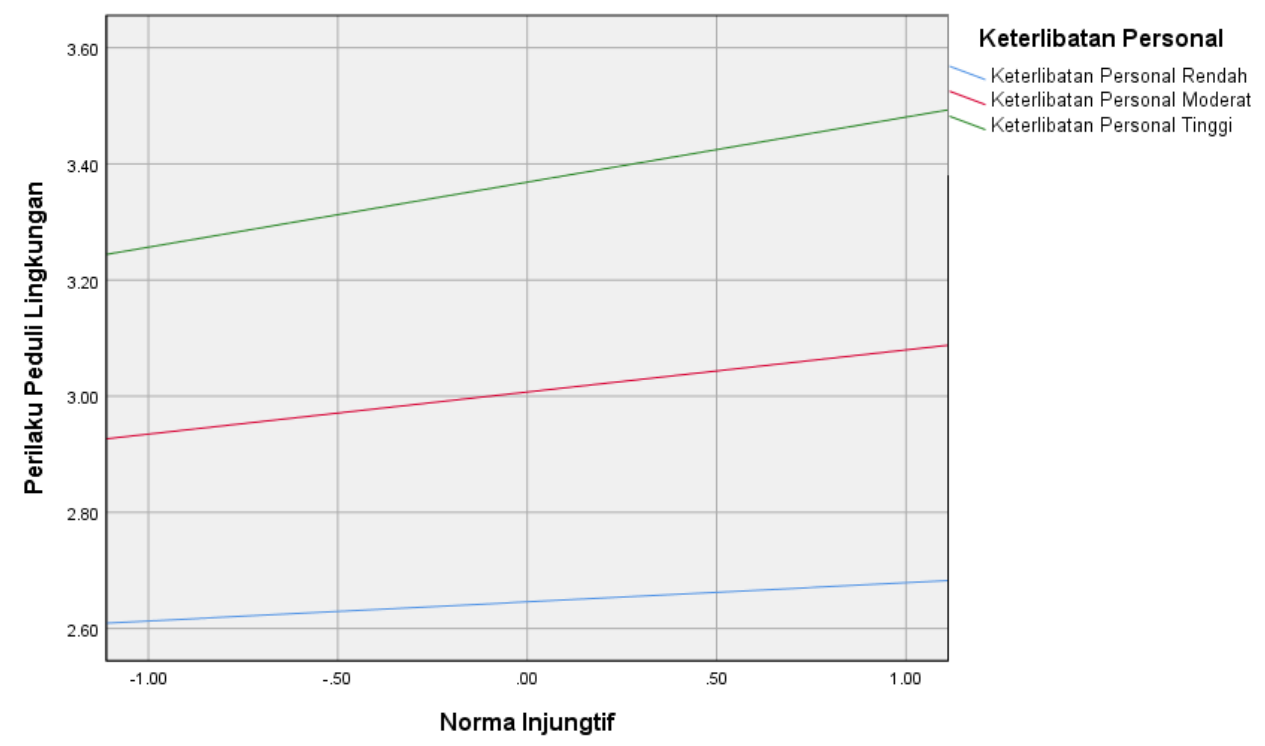

Gambar 4. Interaksi moderasi keterlibatan personal terhadap norma injungtif dan perilaku peduli lingkungan

moderasi terdapat pada norma deskriptif. Berdasarkan data tersebut, norma deskriptif moderat dan tinggi memiliki pengaruh yang cukup baik dalam memoderasi norma injungtif terhadap perilaku peduli ling-kungan. Meskipun hipotesis ketiga ditolak, tetapi masih memiliki pengaruh, terutama pada norma deskriptif moderat dan tinggi.

Keempat, analisis pembuktian pada hipotesis terakhir. Perhitungan model moderasi dapat diterima dengan nilai $\mathrm{F}(3$, $102)=3.671, p<.001, R 2=.293$. Norma injungtif tidak memiliki pengaruh signifikan terhdap perilaku peduli lingkungan $(b=$ $.072, \mathrm{t}(102)=.824, \mathrm{p}=.411)$. Keterlibatan personal memiliki hubungan yang signifikan dengan perilaku lingkungan yakni $\mathrm{b}=.643, \mathrm{t}(102)=-4.221, \mathrm{p}=.000$, yang memiliki arti bahwa setiap kenaikan satu unit keterlibatan personal memberi kenaikan juga pada perilaku peduli lingkungan sebesar .069. Interaksi moderasi keterlibatan personal terhadap hubungan norma injungtif dengan perilaku peduli lingkungan tidak signifikan $(b=.069, t(102)$ $=.241, \mathrm{p}=.310)$. Jika melihat analisis Johnson-Neyman, tidak ada interaksi moderasi yang signifikan melalui keterlibatan personal, baik pada nilai keter- libatan personal rendah, moderat, ataupun tinggi. Grafik dapat dilihat pada Gambar 4. Berdasarkan seluruh analisis yang telah dilakukan, bahwa yang memiliki potensi cukup baik dalam memprediksi adalah moderasi norma deskriptif terhadap hubungan antara norma injungtif pada perilaku peduli lingkungan. Moderasi norma deskriptif tersebut yang mampu memberikan hasil signifikan adalah norma deskriptif bernilai moderat dan tinggi, sedangkan nilai norma deskriptif rendah tidak dapat mempengaruhi secara signifikan dalam memoderasi hubungan antara norma injungtif dan perilaku peduli lingkungan.

\section{Pembahasan}

Hasil analisis data telah menunjukkan bahwa interaksi moderasi norma sosial dan keterlibatan personal tidak memiliki pengaruh yang signifikan terhadap peri-laku peduli lingkungan. Norma deskriptif yang dimoderasi oleh norma injungtif dan keterlibatan personal tidak menghasilkan pengaruh terhadap peningkatan atas perilaku peduli lingkungan. Begitu juga dengan norma injungtif yang dimoderasi oleh keterlibatan personal 
tidak menghasilkan peningkatan perilaku peduli lingkungan. Berdasarkan pernyataan gambaran deskriptif perilaku pengunjung restoran menunjukan bahwa 93\% masih menggunakan sedotan plastik ketika minum, hal ini menunjukan bahwa norma sosial yang berlaku pada restoran tersebut sangat tinggi dalam penggunaan sedotan plastik. Dengan penjelasan sebagian besar pengunjung masih menggunakan sedotan plastik maka perilaku peduli lingkungan dengan mengurangi sedotan masih tidak dicapai.

Berdasarkan riset terdahulu, bahwa norma deskriptif memiliki pengaruh yang konsisten untuk mempengaruhi khususnya pada perilaku peduli lingkungan (Farrow, Grolleau, \& Ibanez, 2017). Oleh karena itu, norma deskriptif yang menggunakan sedotan plastik di restoran ini tidak dapat menghasilkan perilaku peduli lingkungan, sebab norma tersebut bertolak belakang dengan perilaku peduli lingkungan. Untuk menghasilkan norma deskriptif yang mendukung perilaku peduli lingkungan, perlu menciptakan keadaan di mana mayoritas pengunjung restoran tidak menggunakan sedotan plastik. Dengan begitu akan memunculkan norma deskriptif untuk tidak menggunakan sedotan.

Hasil penelitian ini berbeda dengan temuan dari Göckeritz et al. (2010) yang memiliki hasil kebalikannya. Penelitian Göckeritz menunjukan bahwa norma deskriptif memiliki pengaruh untuk memoderasi keyakinan perilaku konservasi. Penelitian tersebut merupakan riset terhadap keyakinan perilaku konservasi secara umum, berbeda pada riset ini yang khusus pada perilaku penggunaan sedotan plastik. Pengurangan sedotan plastik hanya merupakan bagian dari perilaku konservasi itu sendiri. Pemahaman ten-tang perilaku penggunaan sedotan plastik terhadap perlu dipelajari lebih lanjut di penelitian yang akan datang.

Meski demikian, norma injungtif telah menunjukan hasil dalam memoderasi norma deskriptif untuk mengarahkan perilaku ketika kelompok memiliki kecenderungan saling bergantung rendah pada sesama anggota kelompok lainnya. Namun, jika suatu kelompok memiliki kecenderungan saling bergantung yang tinggi pada anggota kelompok lainnya, maka norma injungtif tidak berdampak untuk memoderasi (Yang, 2018). Oleh karena itu, keadaan norma deskriptif akan mempengaruhi perilaku seseorang dalam kelompok sosialnya. Pertimbangan untuk riset mendatang adalah bagaimana mengubah perilaku dengan meningkatkan norma deskriptif yang mendukung ke arah perubahan perilaku.

Analisis berikutnya, norma injungtif yang dimoderasi oleh norma deskriptif memiliki potensi untuk memprediksi dalam meningkatkan perilaku peduli lingkungan, walaupun secara keseluruhan dari interaksi tidak signifikan. Norma injungtif yang dimoderasi oleh nilai norma deskriptif moderat dan tinggi memiliki pengaruh yang signifikan dalam meningkatkan perilaku peduli lingkungan. Hal tersebut menunjukkan adanya interaksi pada norma deskriptif moderat dan tinggi dalam mempengaruhi perilaku peduli lingkungan pengunjung restoran.

Norma injungtif telah terbukti dalam memberikan pesan persuasif yang ditunjukan pada riset sebelumnya (Chung \& Rimal, 2016; de Groot et al., 2013; Jacobson, Mortensen, Jacobson, \& Cialdini, 2015). Potensi norma injungtif juga dapat memoderasi hubungan norma deskriptif terhadap perilaku peduli lingkungan (Cialdini et al., 1991, 1990; Schultz et al., 2016). Namun, pada riset kali ini potensi tersebut muncul pada norma injungtif yang dimoderasi oleh norma deskriptif. Norma injungtif yang dimoderasi oleh norma deskriptif dapat meningkatkan perilaku peduli lingkungan bila nilai dari norma deskriptif tersebut berada pada level moderat dan tinggi.

Permasalahan terjadi ketika keadaan menunjukan bahwa norma deskriptif tidak mendukung perilaku yang diharapkan, seperti pada penelitian ini norma des- 
kriptif masih menunjukan penggunaan sedotan plastik. Jika menggunakan pesan persuasif norma deskriptif bahwa di restoran tersebut sebagian besar tidak menggunakan sedotan plastik, maka akan tidak efektif dalam mengubah perilaku yang diharapkan. Menggunakan pesan norma deskriptif yang berbeda dengan keadaan yang terjadi akan berdampak negatif (Smith et al., 2012). Sebab itu, pemanfaatan norma injungtif menjadi salah satu harapan yang bisa digunakan di penelitian yang akan datang.

Penggunaan pesan norma injungtif juga memiliki pengaruh untuk menghadirkan kewajiban seseorang untuk menyesuaikan dengan kelompok. Norma injungtif menciptakan keadaan akan sanksi sosial, jika tidak menyesuaikan dengan norma injungtif yang berlaku (Cialdini \& Trost, 1998). Meskipun begitu, sanksi sosial akan memiliki pengaruh tinggi jika seseorang benar-benar merasa terafiliasi dengan kelompok tersebut. Sehingga, pesan norma injungtif yang digunakan di restoran lebih baik menunjukan pesan yang memiliki kedekatan dengan pengunjung restoran tersebut.

Selain itu, penggunaan kombinasi norma sosial dapat digunakan lebih jauh untuk memunculkan perilaku peduli lingkungan. Hasil penelitian ini juga sejalan dengan penelitian terdahulu yang memanfaatkan kedua norma tersebut dalam mengarahkan perilaku seseorang (Ariely, Gneezy, \& Haruvy, 2018; Farrow et al., 2017; Plows et al., 2017; Smith \& Louis, 2008). Walaupun menggunakan kombinasi kedua norma deskriptif dan injungtif menunjukan hasil yang baik, tetapi perlu juga memperhatikan dan mempertimbangkan menge-nai setiap karakteristik dari target individu (Halim, Hasking, \& Allen, 2012; Lee, Geisner, Lewis, Neighbors, \& Larimer, 2007).

Berdasarkan penelitian yang dilakukan sebelumnya, bahwa kombinasi dari norma ini dapat mengatasi bumerang efek norma deskriptif. Efek bumerang tersebut memunculkan perilaku tidak diinginkan, sedangkan kehadiran norma injungtif dapat meredam efek bumerang tersebut (Schultz et al., 2016; Schultz, Nolan, Cialdini, Goldstein, \& Griskevicius, 2018). Peran norma injungtif dapat dimanfaatkan lebih jauh sebagai efek kontrol untuk meminimalisir efek yang tidak diinginkan dari norma deskriptif.

Selanjutnya, keterlibatan personal tidak memiliki pengaruh dalam memoderasi norma sosial terhadap perilaku peduli lingkungan. Meskipun keterlibatan personal memiliki peran penting dalam memoderasi suatu perilaku yang diharapkan ketika menyusun pesan persuasif (Bai et al., 2018, 2019). Sehingga dalam memberikan intervensi perubahan perilaku, perlu mencermati lebih dalam mengenai keterlibatan personal ketika ingin memberikan pesan persuasif. Hal ini berlaku khususnya pada fenomena penggunaan sedotan plastik.

Jika melihat jawaban deskriptif dari kuesioner, bahwa responden merasa pengunjung restoran sebagian besar menggunakan sedotan selama minum $(77 \%)$. Hal ini menunjukan bahwa norma deskriptif di restoran tersebut adalah menggunakan sedotan selama minum. Namun, untuk data deskriptif norma injungtif menunjukkan bahwa tidak menggunakan sedotan adalah tindakan peduli lingkungan (54\%). Berdasarkan hasil tersebut, bahwa norma injungtif mampu mendorong perilaku peduli lingkungan meskipun norma deskriptif yang memoderasi menyatakan tidak mendukung perilaku peduli lingkungan.

Penelitian ini menunjukan bahwa jika kemampuan moderasi juga akan meningkat bila kedua norma injungtif dan deskriptif saling mendukung satu sama lain. Pada penelitian yang akan datang perlu membentuk norma deskriptif yang mendukung perilaku peduli lingkungan, lalu dapat diperkuat dengan pemberian norma injungtif. Sehingga, penerapan norma sosial akan lebih maksimal dalam mengarahkan perilaku peduli lingkungan. 


\section{Simpulan}

Berdasarkan penelitian yang dilakukan, dapat dismpulkan bahwa norma injungtif yang dominan terhadap perilaku peduli lingkungan dapat diandalkan untuk memberikan dorongan terhadap perilaku peduli lingkungan. Sedangkan norma deskriptif pada penggunaan sedotan plastik di restoran tidak dapat meningkatkan perilaku peduli lingkungan, hal tersebut disebabkan penggunaan sedotan plastik cukup tinggi di restoran. Norma sosial yang ada di restoran ialah menggunakan sedotan plastik, sehingga jika menggunakan norma deskriptif dalam mengurangi penggunaan sedotan plastik menjadi tidak efektif. Sedangkan, keterlibatan personal juga tidak menunjukkan pengaruh dalam mengarahkan perilaku peduli lingkungan.

\section{Saran}

Hasil penelitian ini masih terbatas pada restoran yang memiliki karakteristik serupa, yakni kategori restoran menengah ke bawah dan dengan jenis pengunjung makan di tempat. Tentu hasil penelitian ini tidak semata-mata langsung dapat digunakan dengan jenis restoran menengah ke atas, yang mana kategori pengunjungnya terbatas pada kelas sosial ekonomi tersebut. Pertimbangan untuk penelitian berikutnya adalah melakukan pengambilan data dengan responden yang lebih banyak di berbagai jenis restoran. Hal ini perlu dilakukan agar mendapatkan kesimpulan lebih dapat digeneralisasikan.

\section{Daftar Pustaka}

Abrams, D., \& Hogg, M. A. (1990). Social Identification, Self-Categorization and Social Influence. European Review of Social Psychology, 1(1), 195-228.

https://doi.org/10.1080/14792779108 401862

Ajzen, I. (2011). The theory of planned behaviour: Reactions and reflections. Psychology and Health, 26(9), 11131127.

https://doi.org/10.1080/08870446.20 11.613995

Ariely, D., Gneezy, U., \& Haruvy, E. (2018). Social Norms and the Price of Zero. Journal of Consumer Psychology, 28(2), 180-191. https://doi.org/10.1002/jcpy.1018

Bai, L., Cai, Z., Lv, Y., Wu, T., Sharma, M., Shi, Z., ... Zhao, Y. (2018). Personal Involvement Moderates Message Framing Effects on Food Safety Education among Medical University Students in Chongqing, China. International Journal of
Environmental Research and Public Health, 15(9), 2059. https://doi.org/10.3390/ijerph150920 59

Bai, L., Rao, Q., Cai, Z., Lv, Y., Wu, T., Shi, Z., ... Hou, X. (2019). Effects of Goal-Framed Messages on Mental Health Education Among Medical University Students: Moderating Role of Personal Involvement. Frontiers in Public Health, 7, 1-9. https://doi.org/10.3389/fpubh.2019.0 0371

Chung, A., \& Rimal, R. N. (2016). Social Norms: A Review. Review of Communication Research, 4, 1-28. https://doi.org/10.12840/issn.22554165.2016.04.01.008

Cialdini, R. B. (2007). Descriptive Social Norms as Underappreciated Sources of Social Control. Psychometrika, $72(2)$ 263-268. https://doi.org/10.1007/s11336-0061560-6

Cialdini, R. B., \& Goldstein, N. J. (2004). 
Social Influence: Compliance and Conformity. Annual Review of Psychology, 55(1), 591-621. https://doi.org/10.1146/annurev.psyc h.55.090902.142015

Cialdini, R. B., Kallgren, C. A., \& Reno, R. R. (1991). A focus theory of normative conduct: A theoretical refinement and re-evaluation. Advances in Experimental Social Psychology, 24, 201-234. https://doi.org/10.1016/ S00652601(08)60330-5

Cialdini, R. B., Reno, R. R., \& Kallgren, C. A. (1990). A focus theory of normative conduct: Recycling the concept of norms to reduce littering in public places. Journal of Personality and Social Psychology, 58(6), 10151026. https://doi.org/10.1037/00223514.58.6.1015

Cialdini, R. B., \& Trost, M. R. (1998). Social influence: Social norms, conformity and compliance. In The handbook of social psychology, Vols. 1-2, 4th ed. (pp. 151-192). New York, NY, US: McGraw-Hill.

de Groot, J. I. M., Abrahamse, W., \& Jones, K. (2013). Persuasive normative messages: The influence of injunctive and personal norms on using free plastic bags. Sustainability (Switzerland), 5(5), 1829-1844. https://doi.org/10.3390/su5051829

de Groot, J., \& Steg, L. (2009). Morality and prosocial behavior: The role of awareness, responsibility, and norms in the norm activation model. Journal of Social Psychology, 149(4), 425449.https://doi.org/10.3200/SOCP.14 9.4.425-449

Dono, J., Webb, J., \& Richardson, B. (2010). The relationship between environmental activism, proenvironmental behaviour and social identity. Journal of Environmental Psychology, 30(2), 178-186. https://doi.org/10.1016/j.jenvp.2009. 11.006

Estrada, M., Schultz, P. W., Messina, A., Tronu, G., Gupta, R., \& Limas, E. F. (2014). Personalized Normative Feedback and the Moderating Role of Personal Norms. Environment and Behavior, 48(5), 686-710. https://doi.org/10.1177/00139165145 53835

Farrow, K., Grolleau, G., \& Ibanez, L. (2017). Social Norms and Proenvironmental Behavior: A Review of the Evidence. Ecological Economics, 140, 1-13. https://doi.org/10.1016/j.ecolecon.20 17.04.017

Göckeritz, S., Schultz, P. W., Rendón, T., Cialdini, R. B., Goldstein, N. J., \& Griskevicius, V. (2010). Descriptive normative beliefs and conservation behavior: The moderating roles of personal involvement and injunctive normative beliefs. European Journal of Social Psychology, 40(3), 514523. https://doi.org/10.1002/ejsp.643

Goldstein, N. J., Cialdini, R. B., \& Griskevicius, V. (2008). A Room with a Viewpoint: Using Social Norms to Motivate Environmental Conservation in Hotels. Journal of Consumer Research, 35(3), 472-482. https://doi.org/10.1086/586910

Greenaway, K. H., Clarke, M. R., Smith, J. R., Cheng, X., Louis, W. R., \& Terry, D. J. (2012). Congruent or conflicted? The impact of injunctive and descriptive norms on environmental intentions. Journal of Environmental Psychology, 32(4), 353-361. https://doi.org/10.1016/j.jenvp.2012. 06.001

Hair, F. Josep, Black, C. William, Babin, J. Barry \& Anderson, E. Rolph, (2018). Multivariate data analysis (eighth edition), United Kingdom, Cengage Learning. 
Halim, A., Hasking, P., \& Allen, F. (2012). The role of social drinking motives in the relationship between social norms and alcohol consumption. Addictive Behaviors, 37(12), 1335-1341. https://doi.org/10.1016/j.addbeh.201 2.07.004

Hayes, A. F., \& Little, T. D. (2018). Introduction to mediation, moderation, and conditional process analysis: a regression-based approach. New York, Guilford Press.

Jacobson, R. P., Mortensen, C. R., Jacobson, K. J. L., \& Cialdini, R. B. (2015). Self-Control Moderates the Effectiveness of Influence Attempts Highlighting Injunctive Social Norms. Social Psychological and Personality Science, 6(6), 718-726. https://doi.org/10.1177/19485506155 78463

Jambeck, J. R., Geyer, R., Wilcox, C., Siegler, T. R., Perryman, M., Andrady, A., ... Law, K. L. (2015). Plastic waste inputs from land into the ocean. Science, 347(6223), 768 LP 771.https://doi.org/10.1126/science.1 260352

Johnson, B. T. \& Eagly, A. H. (1989). Effects of Involvement on Persuasion: A Meta-Analysis. Psychological Bulletin, 106(2), 290314.

https://doi.apa.org/doi/10.1037/00332909.106.2.290

Lee, C. M., Geisner, I. M., Lewis, M. A., Neighbors, C., \& Larimer, M. E. (2007). Social motives and the interaction between descriptive and injunctive norms in college student drinking. Journal of Studies on Alcohol and Drugs, 68(5), 714-721. https://doi.org/10.15288/jsad.2007.6 8.714

McAuliffe, B. J., Jetten, J., Hornsey, M. J., \& Hogg, M. A. (2003). Individualist and collectivist norms: When it's ok to go your own way. European Journal of Social Psychology, 33(1), 57-70.

https://doi.org/10.1002/ejsp.129

Miller, D. T., \& Prentice, D. A. (2016). Changing Norms to Change Behavior. Annual Review of Psychology, 67(1), 339-361. https://doi.org/10.1146/annurevpsych-010814-015013

Nolan, J. M., Schultz, P. W., Cialdini, R. B., Goldstein, N. J., \& Griskevicius, V. (2008). Normative social influence is underdetected. Personality and Social Psychology Bulletin, 34(7), 913-923.

https://doi.org/10.1177/01461672083 16691

Nyborg, K., Anderies, J. M., Dannenberg, A., Lindahl, T., Schill, C., Schlüter, M., ... De Zeeuw, A. (2016). Social norms as solutions. Science, 354(6308), 42-43. https://doi.org/10.1126/science.aaf83 17

Ocean Conservancy. (2017). International coastal cleanup 2017 report. Washington DC. Retrieved from: https://oceanconservancy.org/wpcontent/uploads/2017/06/Internationa 1-Coastal-Cleanup_2017-Report.pdf

Park, S. Y., Son, H., Lee, J., \& Go, E. (2020). Moderating Effects of Social Norms and Alcohol Consumption on Message Framing in Responsible Drinking Campaigns: Value from Deviance Regulation Theory. Health Communication, 35(7), 793-803. https://doi.org/10.1080/10410236.20 19.1593077

Petty, R. E., Cacioppo, J. T., \& Goldman, R. (1981). Personal involvement as a determinant of argument-based persuasion. Journal of Personality and Social Psychology, 41(5), 847855. https://doi.org/10.1037//00223514.41.5.847 
Plows, S. E., Louis, W. R., La Macchia, S. T., Smith, J. R., Chapman, C. M., \& Smith, F. D. (2017). Healthy eating: A beneficial role for perceived norm conflict? Journal of Applied Social Psychology, 47(6), 295-304. https://doi.org/10.1111/jasp.12430

Rimal, R. N., \& Real, K. (2005). How behaviors are influenced by perceived norms a test of the theory of normative social behavior. Communication Research, 32(3), 389-414.

https://doi.org/10.1177/00936502052 75385

Schultz, P. W., Messina, A., Tronu, G., Limas, E. F., Gupta, R., \& Estrada, M. (2016). Personalized Normative Feedback and the Moderating Role of Personal Norms. Environment and Behavior, 48(5), 686-710. https://doi.org/10.1177/00139165145 53835

Schultz, P. W., Nolan, J. M., Cialdini, R. B., Goldstein, N. J., \& Griskevicius, V. (2018). The Constructive, Destructive, and Reconstructive Power of Social Norms: Reprise. Perspectives on Psychological Science, 13(2), 249-254. https://doi.org/10.1177/17456916176 93325

Smith, J. R., \& Louis, W. R. (2008). Do as we say and as we do: The interplay of descriptive and injunctive group norms in the attitude-behaviour relationship. British Journal of Social Psychology, 47(4), 647-666. https://doi.org/10.1348/014466607X 269748

Smith, J. R., Louis, W. R., Terry, D. J., Greenaway, K. H., Clarke, M. R., \& Cheng, X. (2012). Congruent or conflicted? The impact of injunctive and descriptive norms on environmental intentions. Journal of Environmental Psychology, 32(4), 353-361. https://doi.org/10.1016/j.jenvp.2012. 06.001

Steffen, W., Richardson, K., Rockström, J., Cornell, S. E., Fetzer, I., Bennett, E. M., ... Sörlin, S. (2015). Planetary boundaries: Guiding human development on a changing planet. Science, $347(6223)$. https://doi.org/10.1126/science.1259 855

Taylor, J. J., Bing, M., Reynolds, D., Davison, K., \& Ruetzler, T. (2018). Motivation and personal involvement leading to wine consumption. International Journal of Contemporary Hospitality Management, 30(2), 702-719. https://doi.org/10.1108/IJCHM-062016-0335

Terry, D. J., \& Hogg, M. A. (1996). Group norms and the attitude-behavior relationship: A role for group identification. Personality and Social Psychology Bulletin, 22(8), 776-793. https://doi.org/10.1177/01461672962 28002

Tibbetts, J. (2015). Managing Marine Plastic Pollution. Environmental Health Perspectives, 123(4), A90A93. https://doi.org/10.1289/ehp.123-A90

van der Linden, S. (2015). Exploring Beliefs About Bottled Water and Intentions to Reduce Consumption: The Dual-Effect of Social Norm Activation and Persuasive Information. Environment and Behavior, 47(5), 526-550. https://doi.org/10.1177/00139165135 15239

Vesely, S., \& Klöckner, C. A. (2018). Global Social Norms and Environmental Behavior. Environment and Behavior, 50(3), 247-272. https://doi.org/10.1177/00139165177 02190 
Wesley Schultz, P., Tabanico, J. J., \& Rendón, T. (2011). Normative beliefs as agents of influence: Basic processes and real-world applications. Attitudes and Attitude Change, (August), 385-410. https://doi.org/10.4324/97802038380 68

Yang, B. (2018). The Moderating Role of Close versus Distal Peer Injunctive Norms and Interdependent SelfConstrual in the Effects of Descriptive Norms on College
Drinking. Health Communication, 33(6), $762-770$. https://doi.org/10.1080/10410236.20 17.1312202

Zhao, Z., Chen, M., \& Zhang, W. (2019). Social community, personal involvement and psychological processes: A study of impulse buying in the online shopping carnival. Journal of Electronic Commerce Research, 20(4), 255-272. http://www.jecr.org/sites/default/files /2019vol20no4_Paper4.pdf 